\title{
Sistem Prosedur Penjualan, Pembelian dan Penyimpanan bagi UMKM Manufaktur
}

\author{
Permata Ayu Widyasari ${ }^{1}$, Yenny Sugiarti ${ }^{2}$, Nyoman Budhiswara Krishna ${ }^{3}$ \\ 1,2.3 Universitas Surabaya \\ e-mail: ${ }^{1}$ permataayu@staff.ubaya.ac.id, 2yenny_s@staff.ubaya.ac.id, \\ 3nyomanbudhiswara@gmail.com
}

\begin{abstract}
Abstrak
Sistem Manajemen Persediaan sangat penting bagi UMKM. Pertama, karena kebutuhan keakuratan jumlah persediaan. Kedua, untuk efisiensi proses operasional. Terakhir, untuk mengamankan aset perushaan. Permasalahan yang menjadi prioritas UD. KS PRO adalah lemahnya sistem manajemen persediaan. Selama ini pemilik dan staf administrasi tidak mengetahui dengan tepat jumlah persediaan per varian sehingga kadang proses pemenuhan order penjualan harus tertunda/terlambat karena jumlah persediaan belum mencukupi. Tidak adanya informasi mengenai jumlah tiap varian yang tepat juga menyulitkan bagian administrasi untuk menyesuaikan jumlah aset perusahaan (persediaan ) di laporan keuangan. Proses pengawasan terhadap persediaan juga sulit dilakukan. Program pengabdian ini berusaha untuk mengatasi hal tersebut dengan merancang sistem penjualan, pembelian dan penyimpanan sederhana sebagai bagian dari manajemen persediaan. Hasilnya, saat ini tersedia informasi jumlah persediaan bahan baku dan barang jadi untuk setiap varian, sehingga proses perencanaan produksi dan penjualan dapat dilakukan dengan lebih baik. Ketepatan waktu pengiriman barang ke pelanggan dapat ditingkatkan, jumlah aset di laporan keuangan tersaji secara akurat, dan pengawasan terhadap persediaan lebih mudah untuk dilakukan.
\end{abstract}

Kata kunci: UMKM, sistem manajemen persediaan, penjualan, pembelian, penyimpanan

\begin{abstract}
Inventory Management System is very important for SMEs. First, because of the need for accuracy in inventory quantities. Second, for operating efficiency and to safeguard company assets. The main problem of UD. KS PRO is the weakness of the inventory management system. So far, owners and administrative staff do not know the amount of inventory per variant. Sometimes the sales order fulfillment process delayed because finished goods inventory is not available. The absence of information regarding the amount of each variant also makes it difficult for the administration staff to adjust the amount of company assets (inventories) in the financial statements. The process of controlling inventory is also difficult. This program attempts to overcome this by designing a simple sales, purchasing and inventory system as part of inventory management system. As a result, information of the amount of raw material and finished goods inventory for each variant available. The production and sales planning process can be carried out better. The timeliness of the delivery of goods to customers can be improved,
\end{abstract}


the amount of assets in the financial statements is presented accurately, and inventory control is easier to do.

Keywords: SMEs, Inventory management system, sales, purchasing, inventory

\section{Pendahuluan}

\section{Latar Belakang}

Usaha Mikro, Kecil, dan Menegah (UMKM) merupakan faktor pendukung utama yang berkontribusi pada pendapatan nasional, produk domestik bruto, pengurangan pengangguran, eksport, hingga pertumbuhan kewirausahaan (Akindipe, 2014; Pillai, 2014; Saxena, 2012). Walaupun demikian, dalam proses memenuhi permintaan barang maupun jasa secara profesional, UMKM menghadapi berbagai tantangan seperti kurangnya kemampuan manajemen, keterbatasan peralatan dan teknologi, buruknya manajemen persediaan dan kurangnya pendanaan (Akindipe, 2014).

Dibandingkan dengan perusahaan berskala besar, UMKM mempunyai keterbatasan akses untuk mencapai pendanaan secara formal. Hal tersebut menyebab keraguan apakah UMKM akan bisa bertahan dan tumbuh (Beck \& Demirguc-Kunt, 2006). Keterbatasan keuangan membuat UMKM belum bisa memenuhi standar operasi perusahaan dan internal control yang layak. Contohnya, beberapa tugas yang dianggap kurang penting akan dirangkap oleh 1 karyawan. Fenomena lainnya adalah karyawan yang dipekerjakan juga tidak sesuai kualifikasi (underqualified).

Contohnya gudang, terkadang UMKM menganggap bahwa gudang adalah bagian yang remeh. Sehingga UMKM dapat menempatkan karyawan yang kurang berpendidikan atau tidak sesuai kualifikasinya sebagai staff gudang. Selain itu, keluar masuknya barang di gudang juga tidak dikontrol maupun dicatat. Semua karyawan bebas keluar masuk mengambil bahan baku untuk kepentingan produksi maupun barang jadi untuk dikirim ke pelanggan. Tidak jarang, karyawan gudang juga merangkap dengan tugas lain.

Buruknya manajemen persedian terbukti terjadi di beberapa negara. Seperti di Nigeria, salah satu masalah manjemen persedian pada perusahaan manufaktur adalah tidak atau kurangnya edukasi dari staff, ini bisa menyebabkan salah penempatan barang pada jenis gudang atau hilangnya dokumen pencatatan penting (Akindipe, 2014). Di Banlore, India, 40 Small Medium Enterprises di sektor manufaktur mempunyai manajemen sediaan yang buruk (Rajeev, 2008). Bahkan entitas yang menggunakan enterprise resourse planning system, catatan persedian nya masih sering tidak sesuai dengan keadaan fisik sediaan (Chan \& Wang, 2014).

Gudang merupakan tempat penyimpanan bahan baku maupun barang jadi. Kurang baiknya manajemen persedian jelas beresiko pada hilangnya barang (asset safeguard) dan keakuratan pencataan persediaan. Ketika pencatatan persedian tidak rapi, maka 
entitas akan kesulitan untuk mencari maupun mengetahui berapa stok bahan baku maupun barang jadi saat ini.

Tujuan utama dari gudang adalah untuk mengontrol alur barang persediaan, baik bahan baku maupun barang jadi. Barang sebaikanya di manage secara hati hati karena akan berdampak pada waktu and biaya. Penyimpanan yg tidak rapi akan membuat karyawan kerepotan ketika mencari suatu barang, sehingga membuang waktu dan tenaga. (Ramaa et al., 2012; Tejesh \& Neeraja, 2018).

Selanjutnya, pencatatan gudang atau persediaan yang akurat membuat entitas dapat dalam membuat keputusan secara tepat. Ketika pencataan persedian tepat, entitas akan dapat melihat barang mana yang termasuk barang yang dipesan hanya periode tertentu (seasonal product), mana yang menjadi barang yang harus diproduksi secara terus menerus (continuous product), mana barang yang dengan perputaran cepat (quick supply). Hal tersebut akan mebuat harga cenderung lebih stabil dan bisa diprediksi (Bruccoleri et al., 2014; Tejesh \& Neeraja, 2018).

Ketika sebuah UMKM tidak mempunyai sistem persedian yang reliable, maka UMKM dapat kehilangan potensi pendapatan. Ketidakakuratan pencatatan persedian menimbulkan berbagai masalah, contohnya kehilangan produktifitas, produksi barang yang tidak diinginkan, mahalnya biaya penyimpanan, dan penurunan komitmen dari pelanggan. (Muchaendepi et al., 2019). Pelanggan akan memilih entitas yang dinamis, yaitu yang bisa memenuhi permintaan barang secara cepat dan tepat. UMKM akan bersaiang dengan competitor yang lain. Ketika entitas (umkm) bisa memenuhi permintaan pelanggan maka UMKM itulah yang akan survive di pasaran. Oleh sebab itu, hanya UMKM dengan manajemen sedia yang terbaiklah yang dapat mengalahkan entitas yang lain (Muchaendepi et al., 2019).

Tentu fenomena sistem persediaan yang buruk dan ketidakakuratan pencataan persedian juga terjadi pada UMKM di Indonesia. Berdasarkan fenomena - fenomena tersebut, dalam pengabdian masyarakat kali ini penulis mencoba menawarkan solusi berupa prosedur dan sistem pencatan persedian manual yang dapat digunakan oleh UMKM di Indonesia. Sistem manual ini juga mudah digunakan untuk karyawan yang tidak memiliki tingkat pendidikan tinggi.

\section{Analisa situasi dan permasalahan UD. KS PRO}

UD. KS PRO bergerak di bidang industri manufaktur yang berfokus pada pembuatan spare part motor. Pada tahun 2017, kekayaan bersih (tanpa tanah dan bangunan usaha) mencapai 900 juta rupiah dengan omset (kurang lebih) 1,5 Miliar setahun. Berdasarkan undang-undang republik indonesia nomor 20 tahun 2008 tentang usaha mikro, kecil, dan menengah maka UD. KS PRO termasuk pada kategori usaha menengah.

Visi UD. KS PRO adalah membuat produk yang berkualitas dan penuh inovatif. Misi UD. KS PRO adalah mengutamakan kepuasan pelanggan dan siap bersaing. UD. KS 
PRO telah berdiri hampir 12 tahun (sejak tahun 2008) dan terus berfokus pada produksi spare part motor dari produk standar hingga produk variasi. Hal ini menuntut UD. KS PRO terus berinovasi untuk mencapai kepuasan pelanggan dan untum memenangkan persaingan.

Persoalan yang dihadapi UD. KS PRO salah satunya untuk mencapai kepuasan pelanggan adalah ketepatan waktu dalam pengiriman barang, baik itu barang jadi maupun bahan baku. Ketepatan waktu dibutuhkan untuk mencapai kepuasan pelanggan disamping itu juga ketepatan waktu untuk memenangkan persaingan sehingga dibutuhkan adanya manajemen persediaan. Saat ini beberapa pesanan tidak dapat dipenuhi tepat waktu karena belum mencukupinya barang jadi untuk dikirim. Permasalahan yang menjadi prioritas UD. KS PRO adalah manajemen persediaan. Kebutuhan UD. KS PRO adalah manajemen persediaan yang berupa prosedur penjualan baik itu secara tunai maupun kredit, prosedur penerimaan dan pengeluaran bahan baku, dan prosedur penerimaan dan pengeluaran barang jadi. Selama ini pemilik dan staf administrasi tidak mengetahui dengan tepat jumlah persediaan per varian sehingga kadang proses pemenuhan order penjualan harus tertunda/terlambat karena jumlah persediaan barang jadi belum mencukupi, atau bahkan jumlah bahan baku belum mencukupi sehingga harus dilakukan pembelian bahan baku dan produksi lebih dulu. Tidak adanya informasi mengenai jumlah tiap varian yang tepat juga menyulitkan bagian administrasi untuk menyesuaikan jumlah aset perusahaan (persediaan) di laporan keuangan. Proses pengawasan terhadap persediaan juga sulit dilakukan.

Hasil output dari pengabdian masyarakat ini adalah peningkatan penerapan iptek di masyarakat (mekanisasi, IT, dan manajemen) berupa rancangan:

1. Prosedur Pembelian

2. Prosedur Penjualan yang meliputi: a) Prosedur Penjualan Tunai dan Kredit (Pelanggan Ambil Sendiri); b) Prosedur Penjualan Tunai dan Kredit (Barang Dikirim ke Pelanggan)

3. Prosedur yang terkait dengan manajemen sediaan yang meliputi: a) Prosedur Penerimaan dan Pengeluaran Bahan Baku; b) Prosedur Penerimaan dan Pengeluaran Barang Jadi

Pelaksana juga melengkapi prosedur tersebut dengan template dokumen dokumen pendukung transaksi tersebut. Implementasi prosedur yang dirancang oleh tim diharapkan dapat meningkatkan keakuratan penyajian informasi bagi pihak-pihak yang berkepentingan sekaligus juga mengamankan persediaan yang dimiliki UMKM. Adapun tujuan dari penulisan paper ini adalah memberi solusi sederhana bagi pelaku UMKM yang merasa sistem persediannya belum teratur dan rawan hilang.

\section{Metode}

Metode pendekatan yang dilakukan untuk mendeteksi permasalah UD. KS PRO adalah wawancara dan walk through proses transaksi dan siklus akuntansi UD. KS 
PRO, observasi serta wawancara langsung kepada divisi terkait. Dari observasi tersebut, permasalahan terdeteksi bahwa UD. KS PRO mempunyai masalah manajemen persedian.
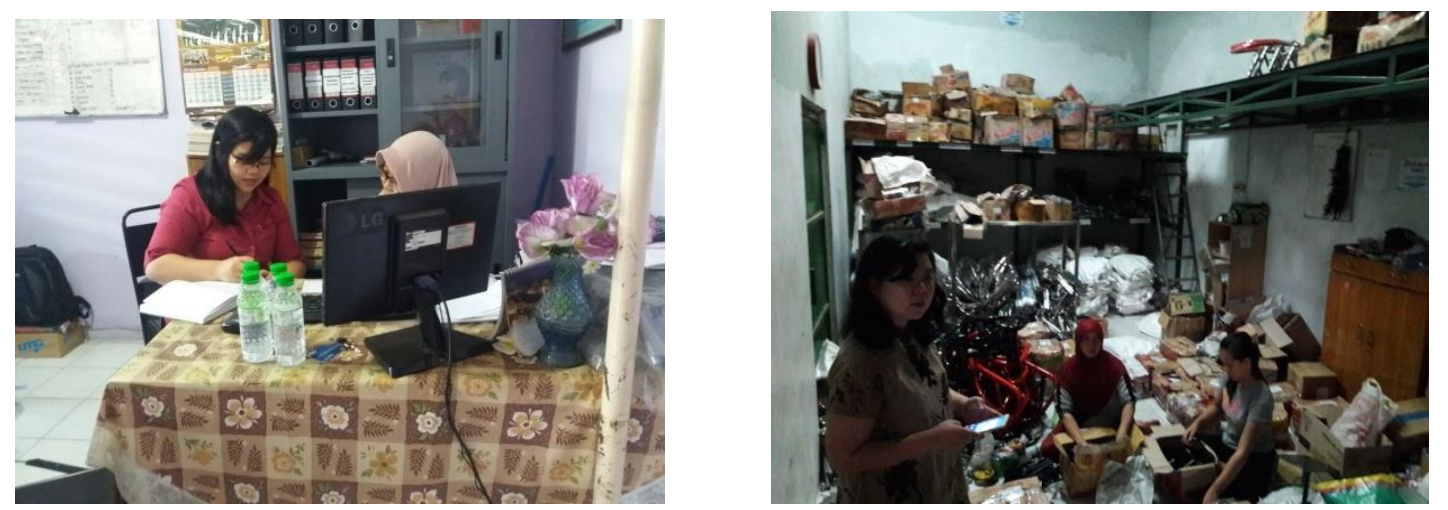

Gambar 1 dan 2. Proses wawancara dan walk-through proses transaksi dan siklus akuntansi

Tahapan selanjutnya adalah merancang prosedur yang berkaitan dengan persedian barang UD. KS PRO. Prosedur tersebut terdiri dari prosedur pembelian, penjualan dan manajemen sedian. Selain itu, untuk memastikan tidak adanya asimetris informasi antara divisi akuntansi dan divisi gudang, dokumen pendukung transaksi seperti tanda terima, dan kartu stock telah kami rancang.

Setelah observasi dilakukan dan mengetahui permasalah yang dihadapi UD. KS PRO, hasil output dari pengapdian masyarakat ini berupa rancangan prosedur pembelian, penjualan dan manajemen sediaan serta dokumen dokumen pendukung transaksi tersebut. Rancangan prosedur dan draft dokumen pendukung transaksi di paparkan kepada pemilik dan divisi akuntansi (pencatat transaksi dan pembuat laporan keuangan). Pemilik juga dapat berkonsultasi secara langsung kepada kami mengenai masalah masalah yang dihadapi. Komunikasi dua arah tersebut menunjukan bahwa pemilik memiliki partisi yang dan peran yang besar dalam menerima rancangan prosedur yang telah kami buat.

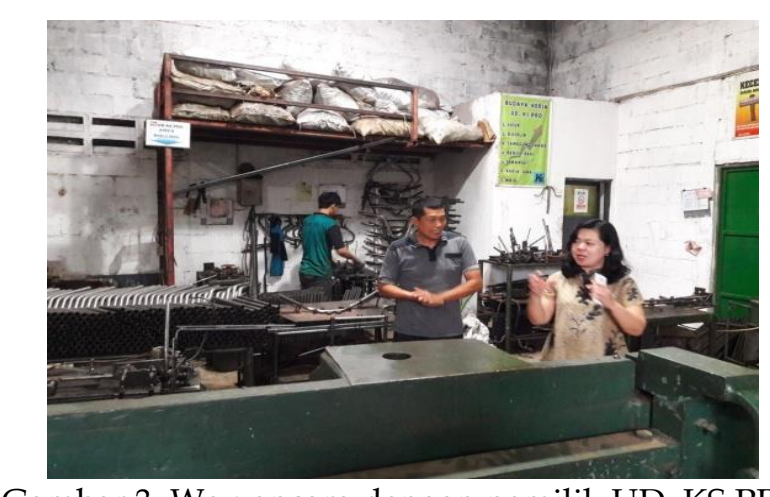

Gambar 3. Wawancara dengan pemilik UD. KS PRO

Pembinanaan pembuatan laporan keuangan dan manajemen sediaan terhadap UD. KS PRO direncanakan menjadi program yang continue. penggunaan rancangan 
prosedur dan draft dokumen pendukung transaksi yang telah dibuat dapat dievaluasi dengan mengadakan kunjungan ke UD. KS PRO.

\section{Hasil dan Pembahasan}

\section{Prosedur Pembelian}

Solusi dari permasalahan yang ada di UD. KS PRO adalah membuatkan prosedur pembelian baik itu secara tunai atau kredit seperti yang dijelaskan dalam tabel berikut: Tabel 1 Prosedur Pembelian

\begin{tabular}{|c|c|c|}
\hline No. & Penanggungjawab & Proses \\
\hline 1. & Gudang & $\begin{array}{l}\text { Menginformasikan kepada pemilik bahwa jumlah persediaan bahan } \\
\text { baku atau sparepart hampir mencapai titik safety stock }\end{array}$ \\
\hline 2. & Pemilik & $\begin{array}{l}\text { Menginformasikan kepada staf administrasi untuk membuat Order } \\
\text { Pembelian ke pemasok bahan baku/sparepart }\end{array}$ \\
\hline 3. & Administrasi & $\begin{array}{l}\text { Menghubungi pemasok untuk menanyakan kesediaan barang. } \\
\checkmark \quad \text { Jika "tersedia" maka membuat Order Pembelian rangkap } 3 \\
\quad-\quad \text { Lembar } 1 \text { diserahkan pada pemasok } \\
\quad-\quad \text { Lembar } 2 \text { diserahkan pada bagian gudang } \\
\quad-\quad \text { Lembar } 3 \text { diarsip } \\
\checkmark \quad \text { Jika "tidak tersedia" maka akan menghubungi pemasok lainnya }\end{array}$ \\
\hline 4. & Gudang & $\begin{array}{l}\text { 1. Pada saat bahan baku/sparepart yang dipesan dikirim oleh pemasok } \\
\text { maka selanjutnya masuk ke prosedur penerimaan dan pengeluaran } \\
\text { bahan baku. } \\
\text { 2. Menandatangani Surat Jalan dari pemasok dan menyerahkan Surat } \\
\text { Jalan ke bagian Administrasi }\end{array}$ \\
\hline 5. & Administrasi & $\begin{array}{l}\text { Menerima Surat Jalan dari bagian Gudang dan Faktur Pembelian dari } \\
\text { pemasok. } \\
\checkmark \quad \text { Jika "pembelian tunai" maka melakukan pembayaran pada pemasok } \\
\text { melalui transfer ataupun langsung dititipkan pada sopir pemasok. } \\
\text { Selanjutnya: } \\
\text { 1. Membuat Bukti Kas Keluar rangkap 2. } \\
\quad-\quad \text { Lembar } 1 \text { diserahkan pada penerima dana } \\
\quad \text { Lembar } 2 \text { diarsip bersama bukti transfer (jika } \\
\text { pembayaran melalui transfer), Faktur Pembelian } \\
\text { beserta Surat Jalan dan Order Pembelian lembar } 1 \\
\text { 2. Mencatat transaksi pembelian dan pengurangan kas } \\
\checkmark \text { Jika "pembelian kredit" maka akan mengarsip Surat Jalan dan Faktur } \\
\text { Pembelian ke Folder utang yang belum jatuh tempo. Pada saat jatuh } \\
\text { tempo maka: } \\
\text { 1. Melakukan pembayaran melalui transfer } \\
\text { 2. Mengarsip Faktur Pembelian beserta Surat Jalan dan Order } \\
\text { Pembelian lembar } 1 \\
\text { 3. Mencatat transaksi pembelian dan pengurangan kas }\end{array}$ \\
\hline
\end{tabular}




\section{Prosedur Penjualan Tunai \& Kredit}

Proses pembelian juga harus dibuatkan prosedurnya sehingga semua bagian yang terlibat memahami setiap langkah yang harus dilaksanakan. Berikut adalah prosedur penjualan baik itu secara tunai atau kredit:

Tabel 2 Prosedur Penjualan Tunai \& Kredit (Pelanggan ambil sendiri)

\begin{tabular}{|c|c|c|}
\hline No. & Penanggungjawab & Proses \\
\hline \multirow{4}{*}{1.} & \multirow{4}{*}{ Gudang } & $\begin{array}{l}\text { 1. Mengambil dan menghitung barang yang akan dikeluarkan untuk } \\
\text { dijual }\end{array}$ \\
\hline & & 2. $\quad$ Membuat Tanda Terima rangkap 2 \\
\hline & & $\begin{array}{l}\text { 3. Meminta salesman pelanggan untuk menandatangani Tanda Terima } \\
\text { lembar } 2\end{array}$ \\
\hline & & $\begin{array}{l}\text { 4. Menyerahkan Tanda Terima lembar } 1 \text { beserta uang pembayaran dari } \\
\text { pelanggan ke bagian administrasi dan mengarsip tanda terima } \\
\text { lembar } 2 \text { berdasarkan tanggal }\end{array}$ \\
\hline \multirow{5}{*}{2.} & \multirow{5}{*}{ Administrasi } & $\begin{array}{l}\text { 1. Menerima Tanda Terima lembar } 1 \text { dan uang pembayaran dari } \\
\text { gudang }\end{array}$ \\
\hline & & 2. Membuat Nota Penjualan rangkap 3 \\
\hline & & - lembar 1 diberikan ke pelanggan \\
\hline & & lembar 2 diberikan ke gudang \\
\hline & & - lembar 3 di arsip berdasarkan nama pelanggan. \\
\hline
\end{tabular}

Tabel 3 Prosedur Penjualan Tunai \& Kredit (Barang dikirim ke pelanggan)

\begin{tabular}{|c|c|c|}
\hline No. & Penanggungjawab & Proses \\
\hline 1. & Administrasi & $\begin{array}{l}\text { 1. Menerima pesanan melalui whatsup atau telepon } \\
\text { 2. Membuat Order Penjualan } 3 \text { rangkap } \\
\text { - lembar } 1 \text { diberikan kepada bagian produksi, } \\
\text { - lembar } 2 \text { diberikan kepada bagian gudang, dan } \\
\text { - lembar } 3 \text { diarsip oleh adminitrasi berdasarkan } \\
\text { nama pelanggan }\end{array}$ \\
\hline 2. & Produksi & $\begin{array}{l}\text { 1. Menerima Order Penjualan lembar } 1 \text { dan melakukan } \\
\text { proses produksi }\end{array}$ \\
\hline 3. & Gudang & $\begin{array}{l}\text { 1. Menerima Order Penjualan lembar } 2 \\
\text { 2. Menyiapkan pengiriman barang sesuai dengan } \\
\text { Order Penjualan lembar } 2\end{array}$ \\
\hline
\end{tabular}

Saat barang siap dikirim

\begin{tabular}{lrl}
\hline Adminitrasi & 1. Membuat Surat Jalan 3 rangkap \\
& $-\quad$ Lembar 1 diberikan kepada pelanggan \\
& $-\quad$ Lembar 2 diberikan kepada bagian gudang \\
& 2. Membuat Nota Penjualan 3 rangkap \\
& $-\quad$ Lembar 1 diberikan kepada pelanggan \\
& $-\quad$ Lembar 2 diberikan kepada gudang \\
& $-\quad$ Lembar 3 diarsip berdasarakan nama \\
& pelanggan
\end{tabular}




5 Gudang
1. $\begin{aligned} & \text { Menerima Surat Jalan lembar } 2 \text { dan Nota Penjualan } \\ & \text { lembar } 2 \text { dari bagian administrasi } \\ & \text { 2enyerahkan Surat Jalan lembar } 2 \text { dan Nota } \\ & \text { Penjualan lembar } 2 \text { ke bagian pengiriman } \\ & \text { Administrasi }\end{aligned} \quad \begin{aligned} & \text { Menerima Surat Jalan lembar 2 dari bagian } \\ & \text { pengiriman dan mengarsipnya berdasarkan tanggal } \\ & \text { pengiriman }\end{aligned}$

Saat Pelunasan

Administrasi
2. jika pelanggan melakukan pelunasan, lembar 3 yang dibawa pelanggan akan ditukarkan dengan lembar 1, kemudian administrasi mengarsipkan lembar 3.

3. mengecek apakah pembayaran telah diterima melalui e-banking

- jika "telah diterima" administrasi akan membukukan piutang berkurang

4. jika "belum diterima" administrasi akan menghubungi pelanggan

Selain membuatkan prosedur penjualan, kami juga membuatkan prosedur penerimaan dan pengeluaaran bahan baku serta barang jadi seperti yang dijelaskan dalam table berikut:

Tabel 4 Prosedur Penerimaan Dan Pengeluaran Bahan Baku

\begin{tabular}{|c|c|c|}
\hline No. & Penanggungjawab & Proses \\
\hline 1. & Gudang & Saat menerima bahan baku: \\
\hline & & $\begin{array}{l}\text { - Mengecek kesesuaian jumlah dan spesifikasi } \\
\text { bahan baku yang diterima dengan Surat Jalan } \\
\text { dan Pemasok. } \\
\checkmark \text { Jika "sesuai" maka mengupdate buku stok } \\
\text { bahan baku, menanda tangani surat jalan } \\
\text { dari pemasok dan menyerahkan Surat jalan } \\
\text { ke bagian Administrasi } \\
\checkmark \text { Jika "tidak sesuai" maka mencoret surat } \\
\text { jalan, kemudian memberikan ke adminitrasi } \\
\text { untuk menyesuaikan akun piutang } \\
\text { pemasok. }\end{array}$ \\
\hline
\end{tabular}

Saat pengeluaran bahan baku :

- Mengambil dan menghitung bahan baku yang akan diserahkan ke bagian produksi,

- update buku stok bahan baku dan meminta bagian produksi untuk tanda tangan di buku stok

- Menginformasikan ke bagian adminitrasi atau pemilik jika bahan baku mendekati safety stok 
- Tiap akhir bulan melakukan stok opname bersama administrasi atau pemilik berdasarkan sampel

- Tiap akhir tahun melakukan stok opname bersama administrasi/ pemilik secara keseluruhan

Tabel 5 Prosedur Penerimaan dan Pengeluaran Barang Jadi

\begin{tabular}{|c|c|c|}
\hline No. & Penanggungjawab & Proses \\
\hline 1. & Gudang & $\begin{array}{l}\text { Saat penerimaan barang jadi : } \\
\text { - } \\
\text { Menghitung dan menerima barang jadi dari } \\
\text { - } \\
\text { Mengupdate kartu stok dan meminta bagian } \\
\text { produksi menandatangani buku stok } \\
\text { Saat pengeluaran barang jadi : } \\
\text { - Mengambil dan menghitung barang jadi yang } \\
\text { akan dikeluarkan untuk dijual } \\
\text { - Update buku stok barang jadi } \\
\text { - Jika salesman/ pelanggan datang sendiri untuk } \\
\text { mengambil barang maka membuat tanda terima } \\
\text { rangkap } 2 \text { dan meminta salesman/ pelanggan } \\
\text { menandatanganinya. } \\
\checkmark \text { lembar } 1 \text { serahkan ke adminitrasi } \\
\checkmark \text { lembar } 2 \text { diarsip berdasarkan tanggal } \\
\text { Jika barang dikirim maka menandatangani Surat } \\
\text { Jalan lembar } 1 \text { dan } 2 \text { dan menyerahkannya } \\
\text { beserta barang yang dikirim kepada bagian } \\
\text { pengiriman } \\
\text { Jika ada retur, maka pihak gudang mencatat } \\
\text { mutasi masuk dibuku stok dan ditanda tangani } \\
\text { oleh pelanggan, kemudian membuat tanda terima } \\
2 \text { rangkap, lembar } 1 \text { diberikan kepada adminitrasi } \\
\text { dan lembar } 2 \text { diarsipkan oleh gudang } \\
\text { Menginformasikan ke administrasi atau pemilik } \\
\text { jika barang jadi mendekati safety stok } \\
\text { Tiap akhir bulan melakukan stok opname } \\
\text { bersama administrasi atau pemilik berdasarkan } \\
\text { sampel } \\
\text { Tiap akhir tahun melakukan stok opname } \\
\text { bersama administrasi/ pemilik } \\
\text { keseluruhan secara }\end{array}$ \\
\hline
\end{tabular}

\section{Dokumen transaksi}

Pengabdian masyarakat ini juga menghasilkan saran berupa adanya dokumen transaksi yang terdiri dari order penjualan, tanda terima, buku stok (buku stok biasa dan buku stok barang yang melalui proses jasa eksternal) 


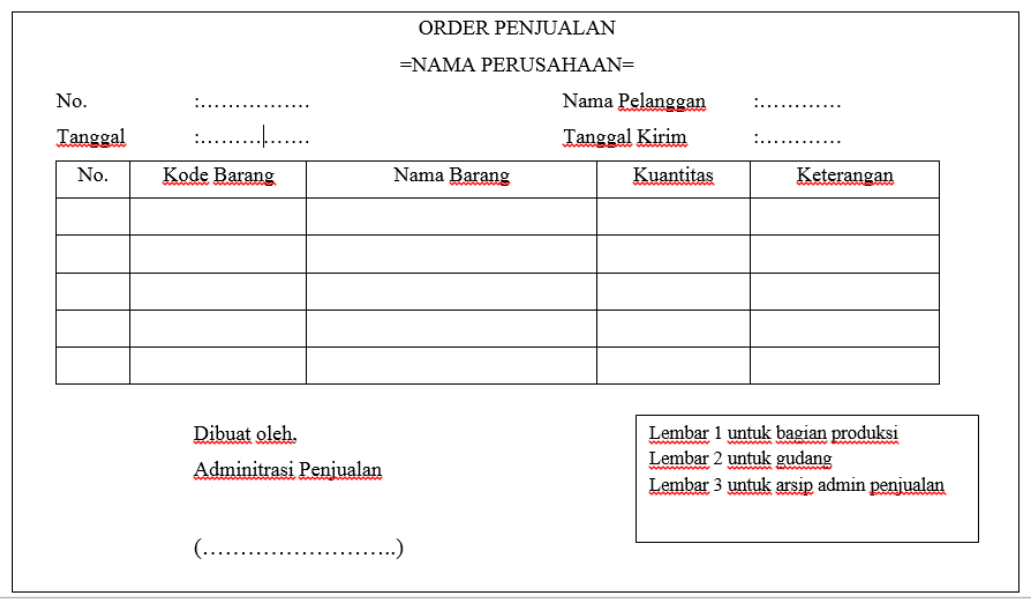

Gambar 4. Order penjualan

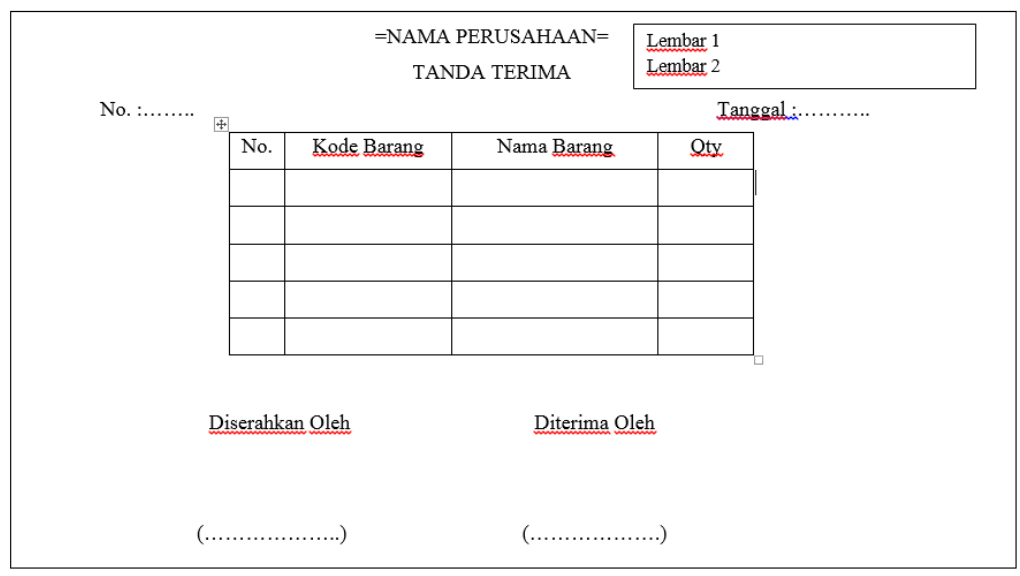

Gambar 5. Tanda terima
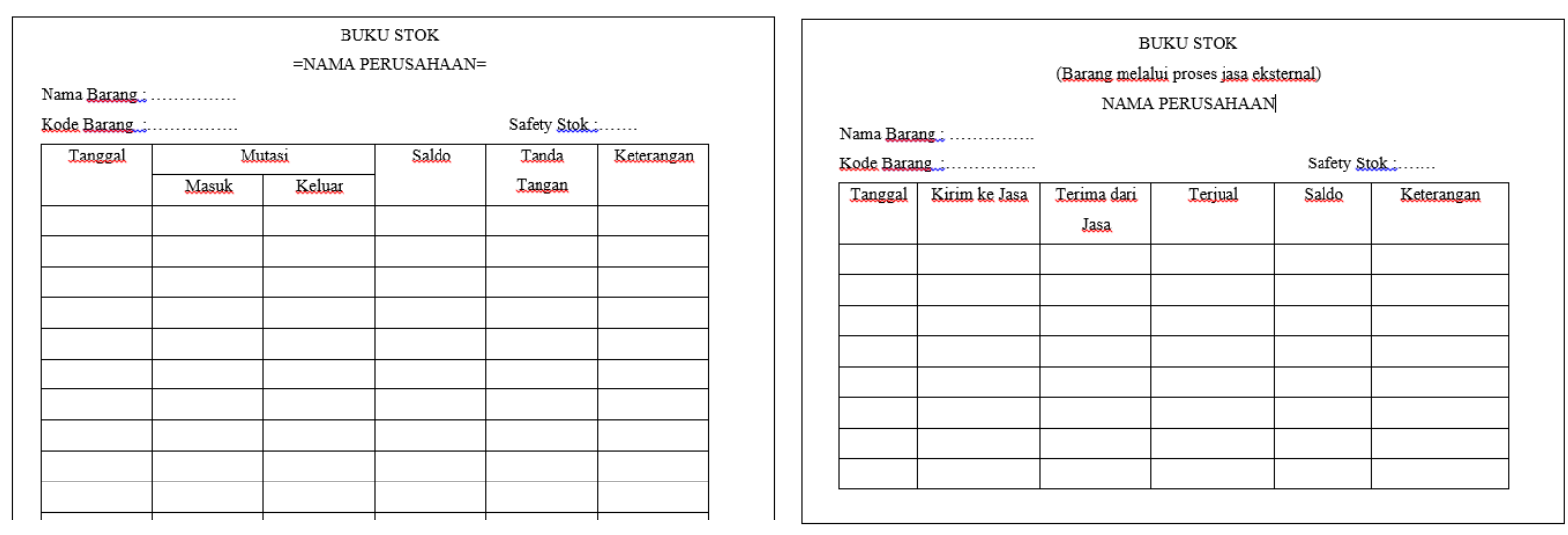

Gambar 6 Buku Stok

\section{Komitmen}

Pemilik UD. KS PRO memiliki komitmen yang sangat tinggi untuk membenahi sistem manajemen persediaan sehingga tim mendapat dukungan penuh dalam hal waktu 
maupun fasilitas yang diperlukan. Di awal perancangan sistem, pemilik beserta staf administrasi dan tim bersama-sama berdiskusi secara intens untuk mendesain sistem manajemen yang sederhana namun memiliki pengendalian internal yang memadai. Pemilik juga mendampingi tim pada saat edukasi staf gudang, sehingga proses edukasi dapat berjalan dengan lancar. Pada saat melakukan simulasi pemeriksaan fisik persediaan pemilik juga ikut serta, sehingga proses simulasi tersebut dapat berlangsung dengan cepat dan dapat melibatkan seluruh staf. Pemilik juga merespon dengan cepat kebutuhan fasilitas yang dibutuhkan dalam sistem ini seperti cetak dokumen dan buku stok.

Staf administrasi juga sangat kooperatif dan memiliki kemauan yang tinggi untuk belajar. Staf administrasi saat ini juga menyusun laporan keuangan secara lengkap sehingga tugas hariannya cukup padat, meski demikian staf administrasi bersedia meluangkan waktunya untuk belajar sistem manajemen persediaan bersama tim. Jika ada hal yang tidak dimengerti, staf administrasi akan menghubungi tim melalui telepon atau email. Staf administrasi juga membantu tim dalam hal koordinasi dengan staf lainnya sehingga proses perancangan dan implementasi dapat diikuti sesuai jadwal.

\section{Kendala}

Ada beberapa kendala yang ditemui tim pada saat implementasi sistem manajemen persediaan, yaitu:

1. Gudang bahan baku sangat sempit sehingga sebagian bahan masih diletakkan di luar ruang. Adanya bahan di luar ruang menyebabkan keamanan bahan baku masih belum maksimal. Gudang barang jadi juga sangat sempit padahal jumlah dan varian yang disimpan cukup banyak sehingga proses layout persediaan belum maksimal. Masih ada barang yang tidak memiliki ruang penyimpanan yang cukup sehingga berhimpitan dengan barang yang lain. Hal ini dapat menyebabkan barang sulit dicari saat dibutuhkan karena kemungkinan bercampur dengan barang lainnya.

2. Staf gudang belum terbiasa untuk tertib mendokumentasikan proses mutasi barang di gudang. Sebelum sistem diimplementasikan belum ada dokumen tanda terima maupun buku stok yang memadai. Pada saat sistem mulai diimplementasikan, karyawan masih terbiasa dengan kebiasaannya yang lama sehingga kadang lupa untuk mengisi tanda terima maupun meng-update data persediaan di kartu stok.

\section{Simpulan dan Rekomendasi}

Masalah yang menjadi prioritas UD. KS PRO pengabdian masyarakat ini sebagai Usaha Mikro, Kecil dan menegah adalah belum adanya manajemen persediaan. Tidak adanya manajemen persediaan menyebabkan perusahaan tidak memperoleh informasi penting saat dibutuhkan seperti jumlah persediaan bahan baku dan barang jadi sehingga berpotensi tidak dapat memenuhi kebutuhan pelanggan tepat waktu, 
selain itu proses pengawasan terhadap arus persediaan juga lemah sehingga potensi untuk salah hitung atau penyalahgunaan persediaan mungkin terjadi. Oleh sebab itu tim merancang sistem menejemen persediaan berupa prosedur penjualan, pembelian dan prosedur penyimpanan sederhana agar persediaan di gudang dapat terpantau. Sistem yang dirancang ini tidak melibatkan banyak pihak yang terlibat karena staf UMKM jumlahnya terbatas, meski sistem yang dibangun memiliki pengendalian internal yang cukup sehingga potensi untuk salah saji maupun potensi penyalahgunaan persediaan dapat diminimalisir. Hasil yang diperoleh setelah sistem diimplementasikan adalah: jumlah persediaan bahan baku dan barang jadi lebih akurat, pemilik dan staf administrasi dapat mengetahui sewaktu-waktu jumlah persediaan untuk tiap varian. Seluruh staf dan karyawan juga merasa lebih paham terhadap tugasnya dalam pengelolaan persediaan. di awal implementasi, ada kendala yang ditemui, yaitu kurang tertibnya karyawan untuk mengisi dokumen, sehingga tim berharap sistem ini dapat terus dilakukan secara konsisten sehingga karyawan akan lebih tertib dan sistem manajemen persediaan ini dapat berjalan efektif.

\section{DAFTAR PUSTAKA}

Akindipe, O. S. (2014). Inventory management-A tool for optimal use of resources and overall efficiency in manufacturing SMEs. Journal of Entrepreneurship, Management and Innovation, 10(4), 93-114.

Beck, T., \& Demirguc-Kunt, A. (2006). Small and medium-size enterprises: Access to finance as a growth constraint. Journal of Banking \& Finance, 30(11), 2931-2943.

Bruccoleri, M., Cannella, S., \& La Porta, G. (2014). Inventory record inaccuracy in supply chains: the role of workers' behavior. International Journal of Physical Distribution \& Logistics Management.

Chan, F. T. S., \& Wang, Z. (2014). Robust production control policy for a multiple machines and multiple product-types manufacturing system with inventory inaccuracy. International Journal of Production Research, 52(16), 4803-4819.

Muchaendepi, W., Mbohwa, C., Hamandishe, T., \& Kanyepe, J. (2019). Inventory management and performance of SMEs in the manufacturing sector of Harare. Procedia Manufacturing, 33, 454-461.

Pillai, R. N. (2014). Factors discriminating inventory management performance: An exploratory study of Indian machine tool SMEs. Journal of Industrial Engineering and Management (JIEM), 7(3), 605-621.

Rajeev, N. (2008). Inventory management in small and medium enterprises: A study of machine tool enterprises in Bangalore. Management Research News.

Ramaa, A., Subramanya, K. N., \& Rangaswamy, T. M. (2012). Impact of warehouse management system in a supply chain. International Journal of Computer Applications, 54(1). 
Saxena, V. D. (2012). Internationalization of small and medium enterprises in India: Opportunities and challenges. South Asian Journal of Marketing $\mathcal{E}$ Management Research, 2(9), 219-228.

Tejesh, B. S. S., \& Neeraja, S. (2018). Warehouse inventory management system using IoT and open source framework. Alexandria Engineering Journal, 57(4), 3817-3823.

Undang-Undang Republik Indonesia Nomor 20 Tahun 2008 Tentang Usaha Mikro, Kecil, Dan Menengah 